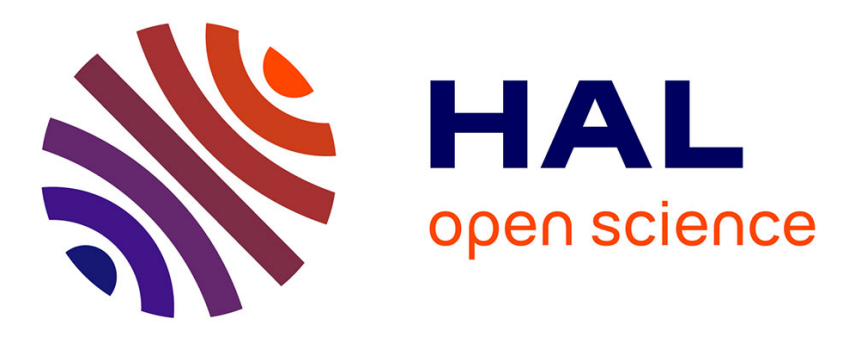

\title{
Local Perceptions, Ruslefac Mapping, and Field Results: The Sediment Budget of Cocagne River, New Brunswick, Canada
}

Guillaume Fortin, Mélanie Leblanc, Sophie Schiavone, Omer Chouinard, Anouk Utzschneider

\section{To cite this version:}

Guillaume Fortin, Mélanie Leblanc, Sophie Schiavone, Omer Chouinard, Anouk Utzschneider. Local Perceptions, Ruslefac Mapping, and Field Results: The Sediment Budget of Cocagne River, New Brunswick, Canada. Environmental Management, 2014, 55 (1), pp.113-127. 10.1007/s00267-0140399-3 . hal-01670319

\section{HAL Id: hal-01670319 https://hal.science/hal-01670319}

Submitted on 25 May 2021

HAL is a multi-disciplinary open access archive for the deposit and dissemination of scientific research documents, whether they are published or not. The documents may come from teaching and research institutions in France or abroad, or from public or private research centers.
L'archive ouverte pluridisciplinaire HAL, est destinée au dépôt et à la diffusion de documents scientifiques de niveau recherche, publiés ou non, émanant des établissements d'enseignement et de recherche français ou étrangers, des laboratoires publics ou privés. 


\title{
Local Perceptions, Ruslefac Mapping, and Field Results: The Sediment Budget of Cocagne River, New Brunswick, Canada
}

\author{
Guillaume Fortin • Mélanie LeBlanc • \\ Sophie Schiavone $\cdot$ Omer Chouinard • \\ Anouk Utzschneider
}

\begin{abstract}
Erosion and sedimentation in water courses represent a major and costly problem everywhere on the planet. Perception of local actors of the state of the river can be a useful source of information to document the river's changes. The main objective of this study consists of understanding how multiple data sources can be used for identifying the most sensitive areas subject to erosion and sedimentation in a watershed. To achieve our objective we combined three complementary methods: conducting interviews, estimating the most sensitive soil loss areas using the Revised Universal Soil Loss Equation for Application in Canada (RUSLEFAC) and taking measurements of environmental variables (turbidity, deposition rate, particle size, water quality, rainfall). The information gathered from the interviews allowed us to determine which areas were the most affected (e.g., either erosion or deposition). However, we observed that there were some
\end{abstract}

G. Fortin $(\square)$

History and Geography Department, Université de Moncton,

Moncton, NB E1A 3E9, Canada

e-mail: guillaume.fortin@umoncton.ca

M. LeBlanc $\cdot$ O. Chouinard

Environmental Studies Program, Université de Moncton,

Moncton, NB E1A 3E9, Canada

S. Schiavone

Geography Department, Université Joseph Fourier,

38100 Grenoble, France

A. Utzschneider

Centre de Formation Médicale du Nouveau-Brunswick,

Moncton, NB E1A 3E9, Canada differences between the areas identified by the participants and those obtained from the RUSLEFAC and in situ measurements. Among these differences, participants identified sites which were the results of misuse or bad practices (e.g., ATV). By contrast sensitive sites for erosion, as identified using RUSLEFAC, are instead areas of steep slopes, located near the river without forest cover. The in situ measurements were very helpful in establishing background values for turbidity but also for comparing quantitative information (e.g., particle size) with what was reported in the interviews.

Keywords Watershed - Sedimentary budget .

Perception · RUSLEFAC $\cdot$ New Brunswick

\section{Introduction}

Over the last 10 years, residents of the Cocagne River watershed (Southeast of New Brunswick, Canada) have voiced their concerns about the deteriorating conditions of the Cocagne River and have demonstrated a keen interest in preventing further degradation of their river (Gauvin, personal communication, 2010). The Cocagne River has ecological, recreational, and economic values for the residents of the many communities through which the river flows. The concerns that have been brought to the forefront are mainly related to erosion and sedimentation. Slaymaker (2003) defines a sediment budget as: “... the accounting of sources, sinks and redistribution pathways of sediment in a unit region over unit time".

Erosion is a natural process but water course deterioration due to erosion increases with human activity. Erosion is generally more important where there is more human activity such as in urban areas (Barton 1977; Kummu 2009; 
Walsh et al. 2005). But even in rural areas with lower population density, other kinds of activities or disturbances such as logging, agriculture, or forest fire can modify land use and have a high potential for inducing erosion and water course deterioration (Barton 1977; Fox 2011; Lewis 1998; Pandey et al. 2007). Soil characteristics and other factors such as precipitation, temperature, and vegetation cover are also important determinants for erosion and sedimentation (Bryan 2000). The economic and environmental costs of erosion can increase substantially when land use change occurs (Pimentel et al. 1995).

Tolerance levels for soil erosion vary greatly throughout the world. In Canada the mean tolerance level is estimated to be 6 tons/hectare/year (3 tons/acre/year) or less (Wall et al. 2002). Using the Revised Universal Soil Loss Equation For Application in Canada (RUSLEFAC), it is possible to calculate the potential for erosion within a watershed (Wall et al. 2002). The simplicity of the equation and the availability of data required for most of the variables have made this a popular method of estimating soil loss potential.

After the sediments resulting from erosion have been transported far enough for deposition to occur, sedimentation ensues. Sediments are an important source of pollution in rivers and streams worldwide, whose negative impact on aquatic ecosystems (Pandey et al. 2007) include higher water temperature, a decrease in the number of spawning areas for many fish species, a decline in habitat for macroinvertebrates and increased turbidity that reduces photosynthesis in the degraded water course (Robertson et al. 2006). The rate at which sediments are deposited (the deposition rate) increases with urban sprawl and development (Allmendinger et al. 2007). Different methods have been used in the past to identify the sources of suspended sediment and their transport and deposition either in the river channel or at the scale of the entire watershed (Collins and Walling 2004; Gao 2008). With the increasing popularity of waterfront properties and activities, the water quality of many rivers are under serious stress and could suffer further degradation without proper mitigation practices. Few studies combine data sources from the social and natural sciences. Our study is a pilot study that combines complementary data sources from the natural and social science in order to assess the potential contributions of such an approach.

The main goal of this research project was therefore to understand how multiple data sources can be used in a complementary manner to identify the most sensitive areas subjected to erosion and sedimentation in a watershed. Local knowledge can be useful for providing information about the state of a watershed and the changes it is undergoing. For example, ethnopedology uses both natural sciences and social sciences to better understand local perceptions of the classification, appraisal, use, and management of the soil
(Barrera-Bassols and Zinck 2003). We used a similar approach here to document and understand the sedimentary budget of a small watershed. We first explored, through individual interviews, the perception of local residents of the condition of the Cocagne River and its erosion/sedimentation problem. We then used RUSLEFAC to create a map that identifies and classifies areas within four levels of potential erosion rates (high, medium, low, and tolerable). On an annual basis, RUSLEFAC is a useful tool for computing erosion in an area, which makes it a good indicator of the quantity of sediment being delivered downstream. We also measured in situ deposition rates, which we combined with other water quality parameters and meteorological data to describe sediment characteristics (grain size, weekly amount of sediment received, etc.) and environmental conditions. While these data were collected for only a single season and are therefore of little value for evaluating longer-term changes, they were collected in an exploratory perspective to verify whether the melding of scientific and community information could improve our understanding of sediment dynamics within a watershed. Finally, we have also identified the multiple stressors causing environmental change within the study area and where they exerted the most pressure on the environment.

\section{Study Area}

The Cocagne River watershed is located in Kent County in the southeastern region of the province of New Brunswick, Canada (Fig. 1). The watershed covers an area of approximately $345 \mathrm{~km}^{2}$ and is drained by the Cocagne River (70 km long), and its many tributaries (Northwest Branch, Shaw Brook, Butler Creek, Murray Brook, and Meadow Brook). The average flow rate of the main branch is $4.6 \mathrm{~m}^{3} / \mathrm{s}$ with peak rates of $49 \mathrm{~m}^{3} / \mathrm{s}$ (Gauvin et al. 2009).

Like many other rivers along the shores of southeastern New Brunswick, the Cocagne River runs into the drainage basin of the Northumberland Strait. Common characteristics of rivers in this area are that they start in wetlands or from a lake and run toward the sea, with estuaries that widen rapidly. Tidal influence on these rivers can go up a few kilometers inland, as is the case with Cocagne River (approximately to site \#5, see Fig. 1).

Many different habitats can be found in this region; closer to the Northumberland Strait we find salt marshes and low undulating hills characterized by forested and agricultural land. In the upper sections of the watershed, there are peat lands (Gauvin et al. 2009). The highest elevation reaches approximately $205 \mathrm{~m}$ above mean sea level (AMSL).

There are no municipalities in the Cocagne River watershed, but there are many local service districts (LSD), 


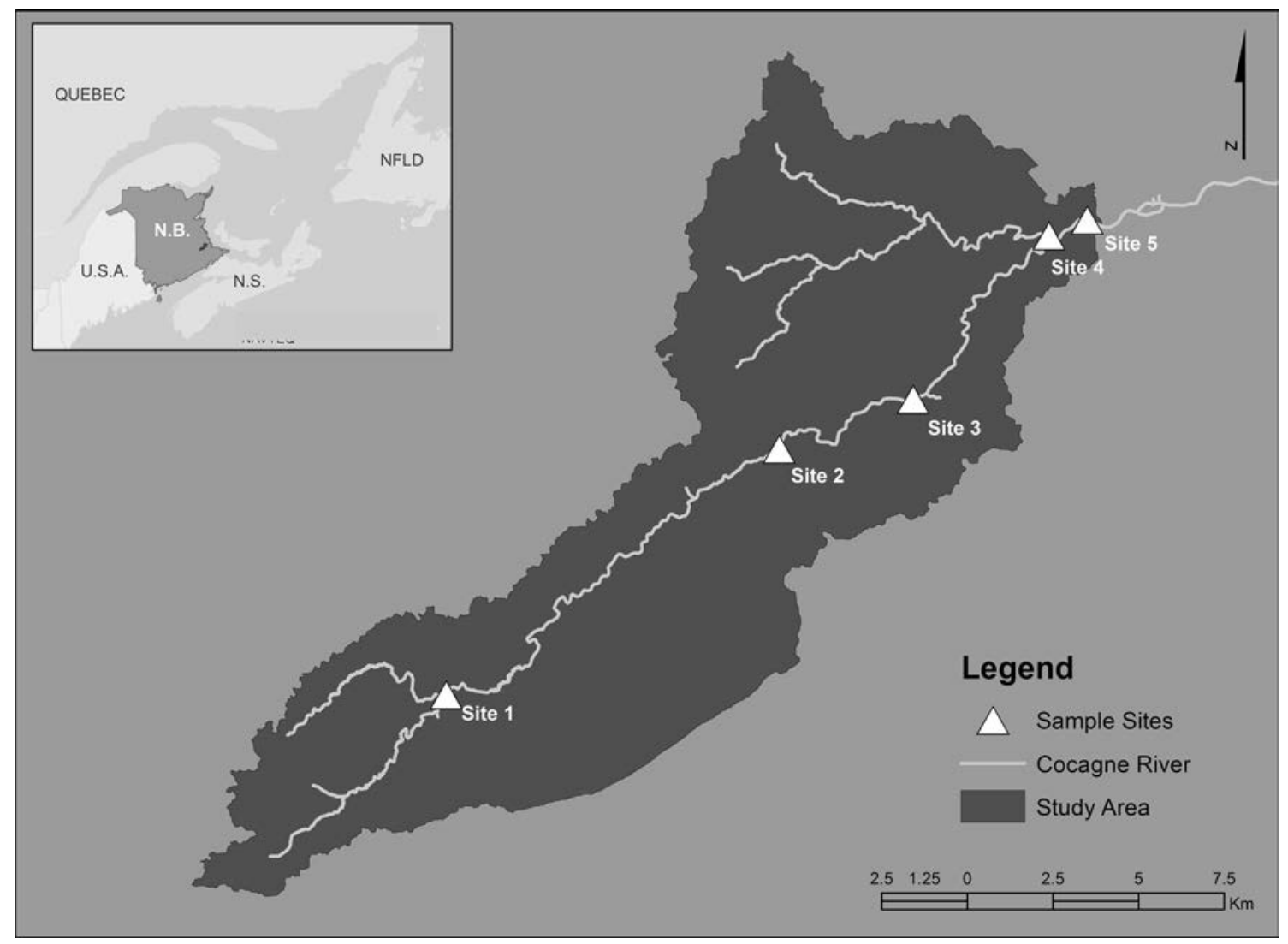

Fig. 1 Location of the Cocagne River and sample sites within the watershed

an administrative unit that was created by the provincial government in order to offer services (such as garbage pick-up, fire department, etc.) to the many smaller communities found in the area (Cocagne, Notre-Dame, Irishtown, Saint-Antoine, and Grande-Digue). The watershed has approximately 3000 permanent residences and many seasonal secondary residences (Gauvin et al. 2009). The local economy is primarily based on natural resources (forest and agriculture) as well as goods and services that are offered in the region.

\section{Materials and Methods}

The first part of this section presents in a broader perspective how the interviews were structured and organized. Subsequently, an explanation of the application of RUSLEFAC is given to understand what factors were used to create a thematic map of the different classes of potential soil loss in the study area. Finally, the last section contains a series of in situ methods and instruments that have been used (sediments traps and a portable weather station) during a limited period of time (July 17, 2011-September 19, 2011).

\section{Semi-structured Interviews}

The local population can provide a significant amount of information on environmental issues, particularly with regard to their perception of a situation (Baum et al. 2006; Dunlap and Michelson 2002; Kindon 2010; Smith et al. 2010). Different participatory approaches and methods can be used to understand people's perception of environmental issues, including semi-structured interviews (Bell et al. 2012; Mustelin et al. 2010). Interviews $(n=15)$ with residents of the watershed (age 35-70 years old; 12 men and 3 women) were conducted during two consecutive summers in 2010-2011. All participants who were selected for interviews were from the community and were identified from a list of river users or riparian owners provided by a local watershed management agency. The semistructured interviews resembled a friendly conversation, thus creating a degree of trust between the interviewee and the interviewer. It is known that this trust can ensure a higher quality of data (Fortin 2010).

The interviews were done following an interview guide (the original survey was written in French and included a total of 30 questions) and a blank map (see appendix 1). The interviews began with some general questions and 
quickly moved toward the blank map so that the explanations could be localized within the study area. They included, for example-Have you ever fished or are you fishing regularly in the river or in the Bay of Cocagne? If so, what species of fish have you caught?-To the best of your knowledge, what are the activities that are practiced around the river in summer and winter?-Do you think the amount of sediment in the river has increased or decreased? Why?-Is there, in your opinion, specific areas of the river where you have noticed an accumulation of sediment on the bottom of the river? Would you be able to identify on the map where this phenomenon occurs?-Do you know where to find information about the state of the river?-Are you aware of any tools (zoning, policy, regulation...) that exist to help prevent or minimize the problems that can affect the river?

The information collected was then analyzed and categorized in one of the following main categories: (1) the river and its use, (2) the state of the river and its sedimentation, and (3) communication-how to create awareness with the users, the residents, and the decision makers.

It is important to solicit local knowledge and traditional environmental knowledge (Mamun 2010; Berkes 2009; Berkes 2007; Berkes et al. 2007; Berkes 2004; Parlee et al. 2006) in order to know the history of the multiple uses of the natural resources and the ecosystem. Local knowledge may also help to complete the interpretation and explanation of scientific data and to understand the biodiversity of an ecosystem, conflicts over use and changes occurs within the watershed, especially as concerns modifications of fish habitat.

\section{RUSLEFAC Mapping}

RUSLEFAC is a valuable tool providing a general overview of soil loss potential for a watershed. This tool can be used for agricultural soil but it is also applicable to nonagricultural conditions such as construction sites (Renard et al. 1997). A revised version of the original equation (USLE) has been developed for applications in Canada by Agriculture and Agri-Food Canada and known as RUSLEFAC (Wall et al. 2002). Both USLE and the RUSLEFAC are calculated as follows (Wischmeier and Smith 1978; Renard et al. 1997):

$A=R \times K \times L \times S \times C \times P$,

where:

$A$ is the potential, long term average annual soil loss in tons per hectare per year (or tons per acre per year).

$R$ is the rainfall factor (MJ mm ha ${ }^{-1} \mathrm{~h}^{-1}$ ).

$K$ is the soil erodibility factor $\left(\mathrm{t} \mathrm{h} \mathrm{MJ}^{-1} \mathrm{~mm}^{-1}\right)$.

$L$ and $S$ are the slope length and steepness factors, respectively (dimensionless).
Table 1 Factors used in the RUSLEFAC equation

\begin{tabular}{ll}
\hline Factor & Source \\
\hline$R$ & $\begin{array}{l}\text { Wall et al. (2002) proposed an R value of } 1550 \mathrm{MJ} \mathrm{mm} \\
\mathrm{ha}^{-1} \mathrm{~h}^{-1} \text { for the study area }\end{array}$ \\
$K$ & $\begin{array}{l}\text { Generalized K values can be estimated based on the work of } \\
\text { Wall et al. (2002) }\end{array}$ \\
$L S \quad$ The LS values were calculated using a Digital Elevation \\
Model originally made by the government of New \\
Brunswick and the ArcHydro module in ArcGIS 9.3.1 \\
A layer containing land use information from the \\
government of New Brunswick was used. Trahan (2002) \\
also provided C values for eight different land use based on \\
the literature that could be used if no data was available for \\
a study area \\
When no data is available for this factor a value of 1 is used \\
(Wall et al. 2002)
\end{tabular}

$C$ is the cropping-management factor (dimensionless).

$P$ is the support practice factor (dimensionless).

The factors used in the RUSLEFAC equation can be obtained or estimated from different sources (Table 1). The software ArcMap 9.3.1 (ESRI) and the ArcHydro 1.4 module were necessary to prepare the thematic map. Using these different data sets we can then calculate soil loss for each pixel in the study area. The value obtained for each pixel is then classified in one of four different classes: tolerable, low, moderate, or high soil loss. Pixels are then grouped to create homogeneous polygons representing the main class of soil loss. The result is a map that graphically represents the location of areas more or less sensitive to water erosion and soil loss.

\section{Sediments Traps and Meteorological Data}

In this study two types of sediment traps, used for fine sediment with mean grain size of less than $50 \mu \mathrm{m}$, were selected for field measurements of the deposition rate in the Cocagne River: (1) sédibac ${ }^{\mathrm{TM}}$ by Bio-Innove Inc. and (2) gravel buckets. In the literature different kinds of sediment traps have been used over time and compared with their respective advantages and disadvantages (Bloesch and Burns 1980; Ice 1986; Luce and Black 1999; Pavey 2006). Traps were chosen for their effectiveness, low cost, and simplicity of use. Both types of sediment traps (three replicas each) were installed at five different sampling sites (Fig. 1). The sites were selected with consideration of river access, the results from the RUSLEFAC map and information shared by local residents during the interviews.

$\operatorname{Sédibac}^{T M}$

Sédibac ${ }^{\mathrm{TM}}$ has been used in many studies (Delisle and Dubé 2001; Dubé et al. 2006; Lachance and Dubé 2004; 
Pavey 2006). This cylindrical sediment trap consists of two perforated containers measuring $12 \mathrm{~cm}$ in diameter and $13.5 \mathrm{~cm}$ high. They are filled with a mesh bag containing clean gravel. The perforations on the cylindrical containers each measure $1.3 \mathrm{~cm}^{2}$ for a total surface area of $39.8 \mathrm{~cm}^{2}$ of open space on the sides of the sediment trap. These perforations allow the natural flow of water and sediments through the bed load.

\section{Gravel Buckets}

Bloesh and Burns (1980) presented some evidence that closed systems could have advantages such as a reduction in turbulence and flow impacts on the collection of sediments. This second method consists of four liters buckets (with a diameter of $20 \mathrm{~cm}$ and a depth of $18 \mathrm{~cm}$ ) filled with gravel and installed in the riverbed.

With both methods, fine sediment $(\leq 50 \mu \mathrm{m})$ was collected weekly. Proper care was taken to ensure that no unnecessary turbulence was created, which could bias the data. The Sédibac ${ }^{\mathrm{TM}}$ and the gravel buckets were emptied into zipper storage bags for transportation to the laboratory. At the laboratory, the samples were transferred into beakers for decantation during a minimal period of $12 \mathrm{~h}$, after which excess water was removed. Afterward, sediments were heated on a hotplate until the remaining water was evaporated thus completing the drying process. The sediments were then weighed and submitted to a burning process $\left(500{ }^{\circ} \mathrm{C}\right.$ for $\left.6 \mathrm{~h}\right)$ to determine the proportion of organic matter. The sediments were then sifted using a mechanical sieve shaker in order to determine the grain size distribution.

We also collected water quality parameters weekly, during the study period. Water temperature, atmospheric pressure, dissolved oxygen, specific (at $25^{\circ} \mathrm{C}$ ) conductivity, $\mathrm{pH}$, salinity, and total dissolved solids were measured using a YSI Professional Plus Handheld Multiparameter Instrument. The speed of the water current was measured using a Global FP111 Flow Probe and the turbidity was measured once in laboratory with a LaMotte 2020 handheld Turbidity Meter.

\section{Meteorological Data Acquisition}

Finally, in addition to collecting in situ data we also installed a portable weather station in the study area. Meteorological measurements were made in an open area $\left(46^{\circ} 19^{\prime} 21.56^{\prime \prime} \mathrm{N}, 64^{\circ} 43^{\prime} 46.79^{\prime \prime} \mathrm{W}\right)$ at an elevation of $35 \mathrm{~m}$ AMSL and at a distance of approximately $800 \mathrm{~m}$ from the Cocagne River. A portable weather station (Onset Hobo Weather Station) recorded precipitation, solar radiation, air temperature, relative humidity, soil moisture, atmospheric pressure, as well as wind velocity and direction from July 17, 2011 to September 19, 2011.
The most important parameter, to achieve our goal were precipitation amount and intensity, which relates to soil losses from water erosion. To ensure that our data was in accordance with the weather's regional patterns, we compared the results from the Hobo station with two nearby weather stations from the national network of Environment Canada (Buctouche CDA CS, $46^{\circ} 25^{\prime} 49.01^{\prime \prime} \mathrm{N}$, $64^{\circ} 46^{\prime} 05.01^{\prime \prime} \mathrm{W}, 35.9 \mathrm{~m}$ AMSL and Moncton Airport $46^{\circ} 06^{\prime} 44.00^{\prime \prime} \mathrm{N}, 64^{\circ} 40^{\prime} 43.00^{\prime \prime} \mathrm{W}, 70.7 \mathrm{~m}$ AMSL, Department of Environment, Canada 2011). We have done two simple linear regressions for hourly precipitation data from our Hobo station with Buctouche and Moncton stations. Our Hobo station has shown a very good fit (respectively $R^{2}=0.92$ for the first and $R^{2}=0.88$ for the latter) meaning that our station was in good agreement with the others and recorded most of the same weather patterns (rainfall events for example).

\section{Results and Discussion}

In this section, we first describe what were the most important issues as perceived by the local population and we locate the most sensitive areas within the catchment area according to the interviewees. We then identify the most sensitive areas for soil losses from water erosion using RUSLEFAC. Finally, in situ data allows us to improve our understanding of the sediment sources and sinks. We also identify the challenges related to improving the water quality of the river.

\section{Interviews}

The first observation from the results of the interviews is that most of the interviewees consider the Cocagne River to be an integral part of their life: "it makes the territory's identity" but also "people's identity" as said by an interviewee. All of them declared with conviction that it is important to guarantee the quality of life along the river.

\section{The River and Its Use}

The Cocagne River is essentially used for leisure activities even if some of the interviewees also use it for their occupation (especially fishing). Boating and fishing are the activities most cited. Boating includes sailing and kayaking. Recreational fishing was practiced by 11 persons out of 15 (Fig. 2). Most of them go (or used to go) fishing occasionally. Salmon, trout, and smelt are the most common species found in the Cocagne River (Gauvin et al. 2009). In a previous study in the same area by (Caissie 2006) it was mentioned that the salmon could be affected negatively by an increase of fine sediment in the river. 
Fig. 2 Principal activities practiced within the Cocagne River watershed by interviewees

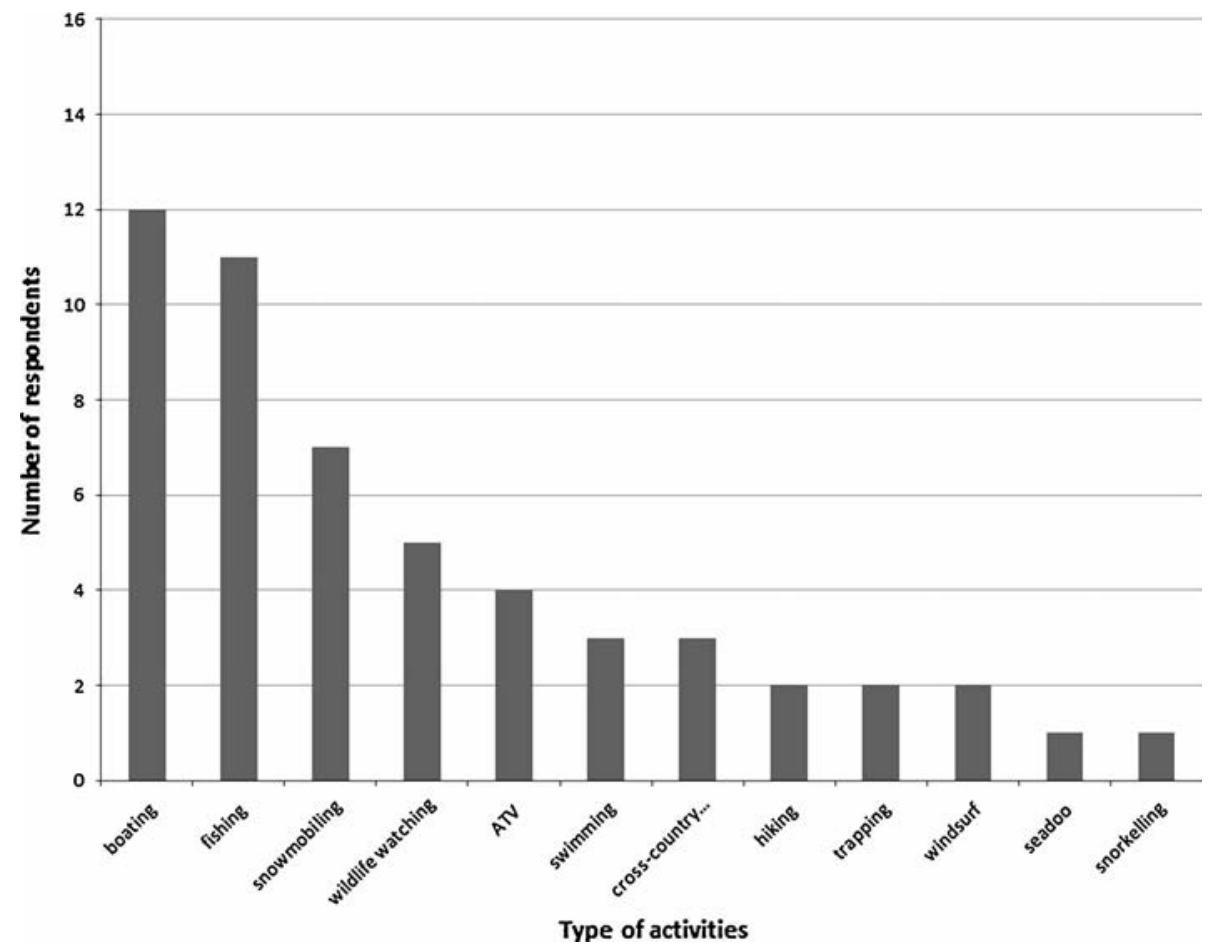

Table 2 Verbatim extract about water quality of the Cocagne River

Verbatim extract

"All of the chalets which have been built, everything created pollution"

“...in residential areas, downstream, quality is worse"

According to interviewees, the Cocagne River banks are also very popular with ATV riders. This topic raised much criticism during the interviews, as we will see below. Among the interviewees, 6 out of 15 persons said they practice ATV along the river. All of the riders said they are members of a club and well informed about best practices and conduct to minimize negative impacts of their activity on the environment.

\section{Sedimentary Budget in the Cocagne Watershed/River}

During interviews, it became apparent that the condition of the Cocagne River is a concern, especially in relation to water pollution, erosion, and sedimentation. Some of these issues seem to be directly related to the use of the territory. Among interviewees, opinions differed slightly concerning water quality and wildlife habitat conditions along the Cocagne River. Overall, water quality and wildlife habitat were judged as being in good condition with some reservations about certain sections of the river, especially downstream (below site \#5, near the bay) where houses are located (Table 2).
Table 3 Verbatim extract about erosion in the Cocagne River

Verbatim extract

Erosion "We have lost terrain over the past 8 years"

"At the NW branch, [...] there are more erosion gullies"

"Along the path, the bank collapsed down the river"

"A rock peak was destroyed in 1960"

Sedimentation "The canal close to the old bridge disappeared, it silted up. It is much shallower than it was"

"The downstream river is filling up, it is shallower"

When asked about significant changes on the river over the past 30 years, erosion and sedimentation were the two most frequent words that came out. Interviewees were able to identify where these problems were located in the watershed, and it appeared that the upstream zone was more affected by erosion whereas the downstream zone was more affected by sedimentation (Fig. 1; Table 3).

All of these comments allowed us to continue the interview talking about river conditions and its sedimentary dynamic. As a first question targeting sedimentation issues, people were asked whether, in their opinion, sediment quantity has tended to increase or decrease. An explanation was also expected. A great majority $(73 \%)$ of the interviewees noticed that the quantity of sediments in the river had a tendency to increase. Only one person noticed a decrease: "I have the impression that it has decreased because of works done by the river organization, the 
Fig. 3 Main factors contributing to soil erosion according to interviewees

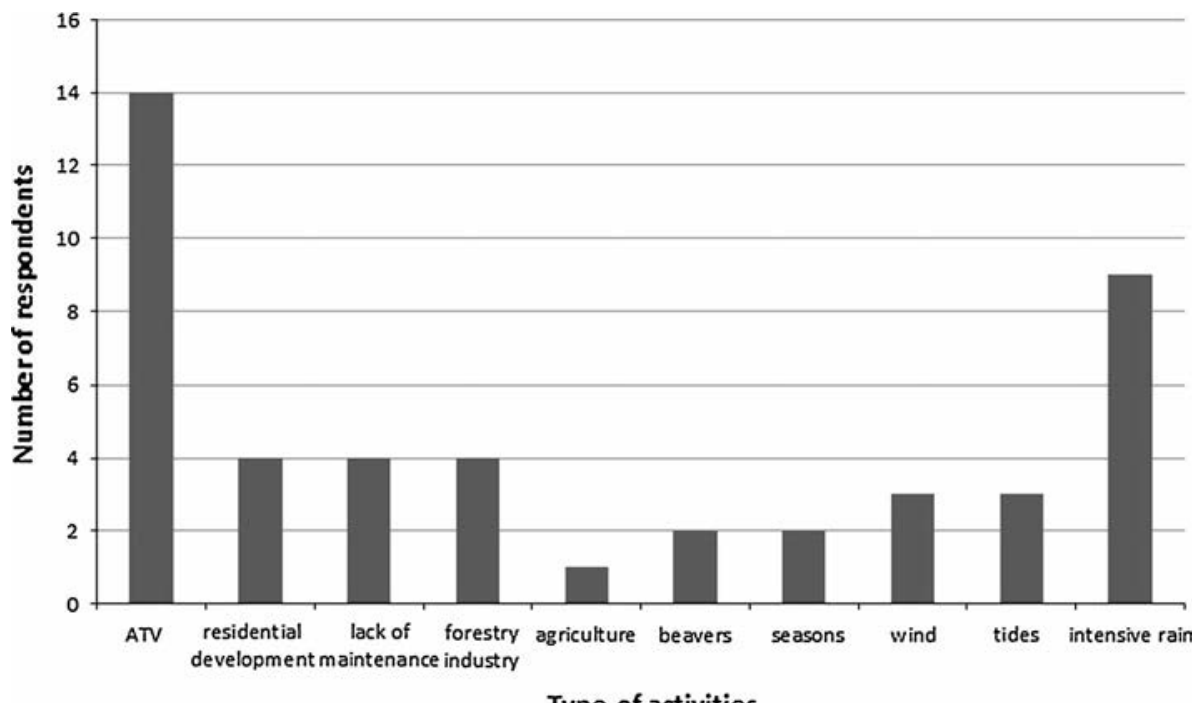

Type of activities respect of forestry cuts, and buffer zones". One person did not answer the question and two others did not see significant changes in sediment activity. For one of them, the sand was replaced by mud: "There is less sand, but more mud". This statement means that there seems to be more silt and clay (fine sediments).

Both human and natural forces were invoked by interviewees to explain the changes in the sedimentary dynamic of the Cocagne River (Fig. 3). ATVs were identified as being the principal damaging human activity on the river. Ten interviewees out of 15 criticized the fact that they ride in the rivers and on pathways along it-often carelessly. The forest industry (through the creation of dirt roads) and residential development near the Cocagne River were also mentioned, but without more precise explanation. According to the interviewees, natural phenomena could also have an impact on the sedimentary dynamic of the Cocagne River. Heavy rains, high tides, and seasonal cycles (freeze/thaw) seem to be the most influential natural phenomena.

Interviewees were able to identify, on a blank map of the Cocagne River watershed, zones that seemed to be affected either by natural erosion or sedimentation and those which appeared to be caused by users. The most impacted sectors are the NW junction, Murray Brook, the bay, and Mack Bass stream (mostly in the southeast of the watershed, Fig. 1). Except Pitt and Willyburg roads, where there is no evidence of sediment nor erosion but where there is clear damage caused by users, there is a significant correlation between sites affected by erosion or sedimentation and those impacted by users.

\section{Communication and Territory Actors}

In general, interviewees are worried about river conditions. Except for two people, all of the interviewees took into
Table 4 Verbatim extract about river protection actions

Verbatim extract

"At home, I make sure that everything is done properly; for example: septic tank maintenance, sediment trapping, etc"

"I gather up as much sediments as I can in my terrain"

"I ride my ATV with caution, and I bring back home all of my garbage when I go fishing. I also inform authorities when I am a witness of a bad act"

"When I mow, I leave a buffer zone close to the riverbank"

consideration possible impacts on the river in their decisions and actions. They try to preserve Cocagne's natural environment (Table 4).

Even if most interviewees know where to gather information about the river's conditions (GDDPC, New Brunswick Department of Natural Resources or Department of Fisheries and Oceans Canada), they believe that more public communication should be done in order to heighten users awareness through meetings, pamphlets, and websites. Most of the interviewees think that nothing can be done without support from local and provincial institutions. There are regulations to prevent erosion and sedimentation (buffer zones for example) but most of the time they are not followed or enforced. Institutions need to be more involved with that issue.

Lastly, interviewees were asked to think about priorities they would like to see improve in the years to come. Examples cited included the creation of special-interest groups working with institutions, with priority given to the understanding of ongoing territorial issues around the Cocagne River. Participants also emphasized the importance of controlling residential development, maintaining dirt roads, and improving education for users. 
Semi-structured interviews provide relevant information complementary to quantitative data which often cover only a short period of time and often a small area. They help to better understand sediment dynamics for the entire study area and its temporal evolution. Yet, the perception of the state of the environment remains subjective and varies according to the participants. It is still possible to reach some consensus among the participants thanks to the use of the blank map. We also noticed that participants mainly identified anthropogenic stressors. The degraded sites are indeed relatively easy to identify in the field when they result from human activities (illegal crossing of ATV in the river, forest road not maintained).

\section{RUSLEFAC Mapping}

As a complement to the interviews, we used the RUSLEFAC application which allowed the creation of a map (Ligonja and Shrestha 2013), where the territory is classified into four main classes of soil loss as proposed by Wall et al. (2002) (Fig. 4): tolerable, low, moderate, and high. This map showed us that the $L S$ factor is important for areas that are typically in the vicinity of the river. When the distance between a surface and the river is large (usually greater than about $133 \mathrm{~m}$ for our watershed), the sediments transported by water will not reach the river. The slope length vary depending on inclination and could be estimated using the digital elevation model. The "slope length is defined as the horizontal distance from the origin of overland flow to the point where either (1) the slope gradient decreases enough that deposition begins or (2) runoff becomes concentrated in a defined channel" as defined by Renard et al. (1997). These authors indicate that slope lengths seldom exceed 400 foot $( \pm 122 \mathrm{~m})$, although occasionally they may be found as long as 1,000 foot $( \pm 305 \mathrm{~m})$. Our values are within the value range suggested by Renard et al. (1997). The majority of the land in our study area is relatively flat, except at the river banks and in a small area in the southern part near the border of the watershed, which partly explains why the vast majority of the territory is classified as tolerable. Other important factors that explained the distribution of the different classes of soil loss are land cover and land use. A large section of the territory, especially near the head of the river, is forested, which limits soil erosion and sediment transport. Areas that appear to be most affected are mainly located either on the edge of the stream (residential) or along the main and secondary roads, including logging roads and ATV trails. But as shown by Nearing et al. (1999) soil erosion prediction can entail a large number of errors. Nearing et al. (1999) also observed that "...the coefficient of variation in soil erosion data tends to be much greater when measured soil loss values are relatively small," which could apply to part of our study area.

The thematic map (Fig. 4) is based primarily on physical characteristics (slope length and steepness factors, soil erodibility factor and so on), although includes land use classes, which depend on human activity. It is partly for this reason that there is some distortion between locations that are classified as highly erodible and those identified by participants as having erosion problems. As we noted above, only a few places were identified by interviewees as having serious erosion problems. These problems are located at specific sites and are caused by human activities. While site characteristics can lead to erosion, according to RUSLEFAC erosion is mostly related to places where human activities are associated with steep slopes over short distances (less than $133 \mathrm{~m}$ as mentioned above) and near the river. In accordance with this observation we found that only a few sites both are considered to be at risk (based on RUSLEFAC) and are actually affected by water erosion problems. Mapping offers many advantages such as a complete and rapid visual overview of an area to document suspended sediment sources and sinks. It also has some disadvantages, such as subjectivity (for map interpretation) that makes it difficult to determine whether eroded areas are contemporary or historical. Mapping is also time-consuming and requires cartographic skills, as mentioned by Collins and Walling (2004).

\section{Field Measurements and Meteorological Data}

\section{Turbidity}

Canadian Water Quality Guidelines for the Protection of Aquatic Life (Canadian Council of Ministers of the Environment 2002) suggest that an increase of more than 8 nephelometric turbidity units (NTU) in turbidity for shortterm exposure (i.e., $24 \mathrm{~h}$ ) or an augmentation of 2 NTU for long-term exposure could be detrimental to aquatic life. These values are based on an increase above the background concentration at clear flow. It has been observed that a value of $30 \mathrm{NTU}$ or more has significant effects on the feeding efficiency on juvenile salmon (Arndt et al. 2002). Arndt et al. (2002) have measured values above 30 NTU in some New Brunswick rivers after flood events but our results are well below this threshold.

Given that our turbidity measurements for July 18, 2011 were very close in value and that there was little precipitations recorded for the week prior to sampling, we used the average of these values as the background concentration at clear flow (2.1 NTU). Therefore, thresholds of 2.0 and 8.0 NTU are set at 4.1 and 10.1 NTU in accordance with the critical exposure level at short and long term for the aquatic life, as mentioned above (Fig. 5). 


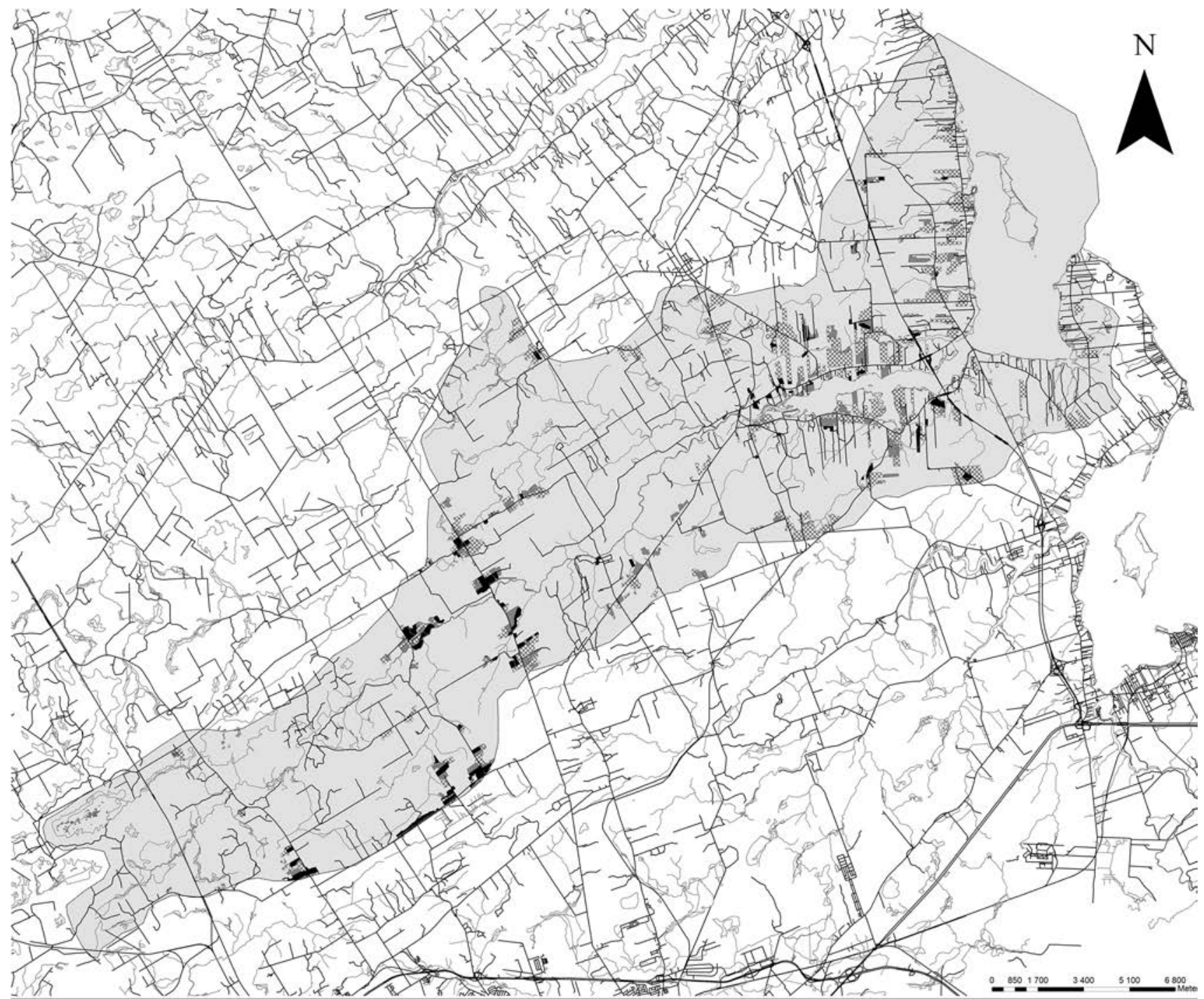

\section{Legend}

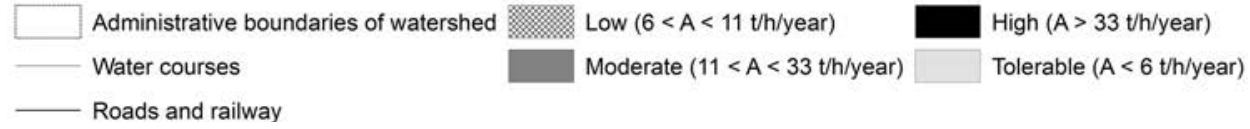

Fig. 4 Soil loss map of the study area using RUCSLEFA

At sites 1, 2, and 3 (the higher section of the river) we observed an increase in turbidity, which surpassed the threshold of 4.1 NTU. However, sites 4 and 5 did not exceed this threshold during our measurement period. The threshold of 10.1 NTU was exceeded only once (August 23) for a single site (site 2). This high value (10.2 NTU) is probably the result of several episodes of heavy rain that occurred in the previous days (as described further in Sect. 4.3.3.). It must be noted that turbidity was measured weekly and therefore could have fluctuated between sample times and peak turbidity could have been missed. An evidence of increases of sediment amount in the river has been captured by time lapse cameras deployed at sites \#1, \#3, and \#5 for this purpose.

Little information on turbidity was collected through interviews and the RUSLEFAC thematic map does not provide data closely related to this variable.

\section{Grain Size Distribution}

As turbidity is directly related to sediment contribution from surface water flow, grain size is also related to the 
Fig. 5 Turbidity values variations during summer 2011
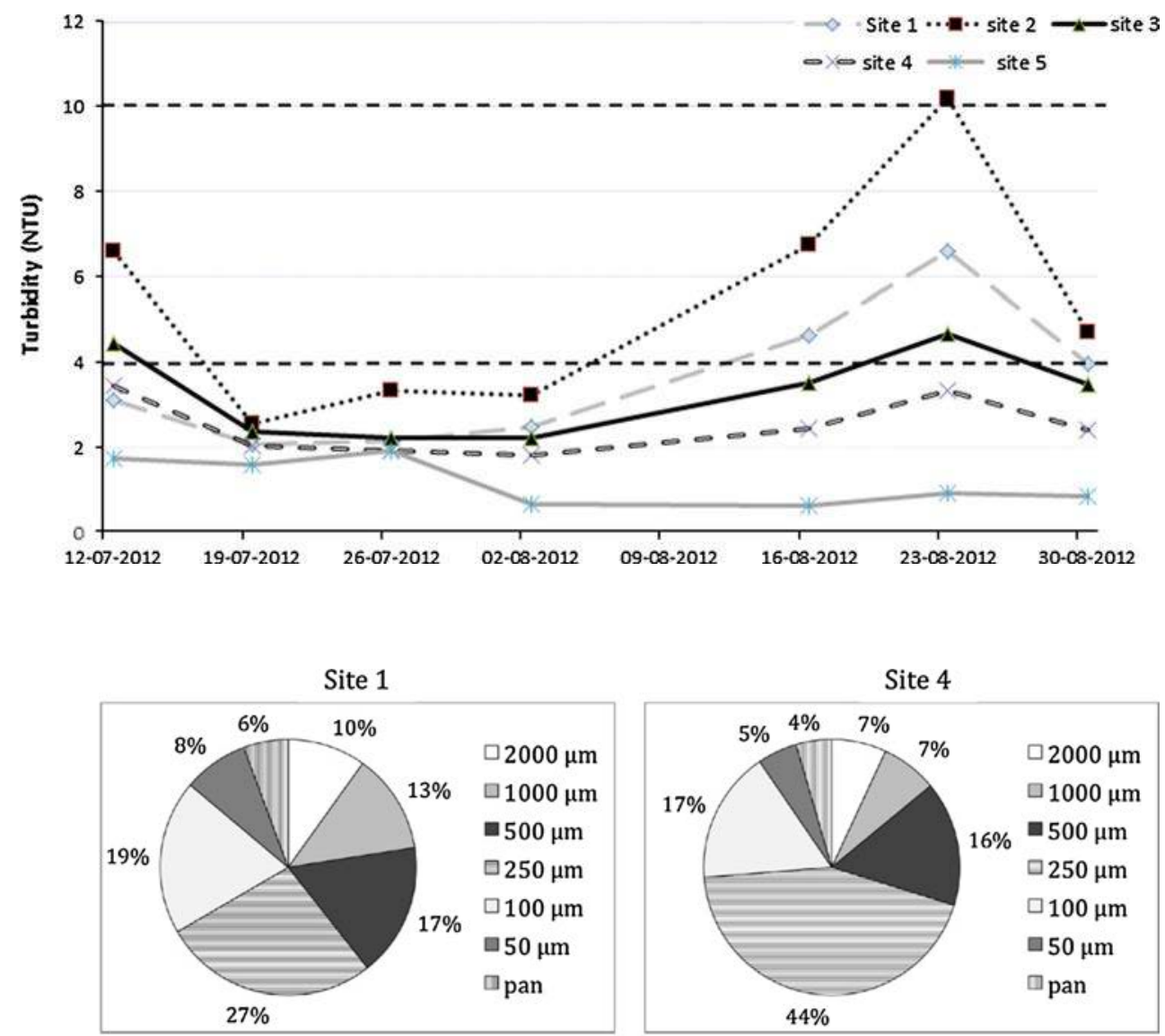

Site 2
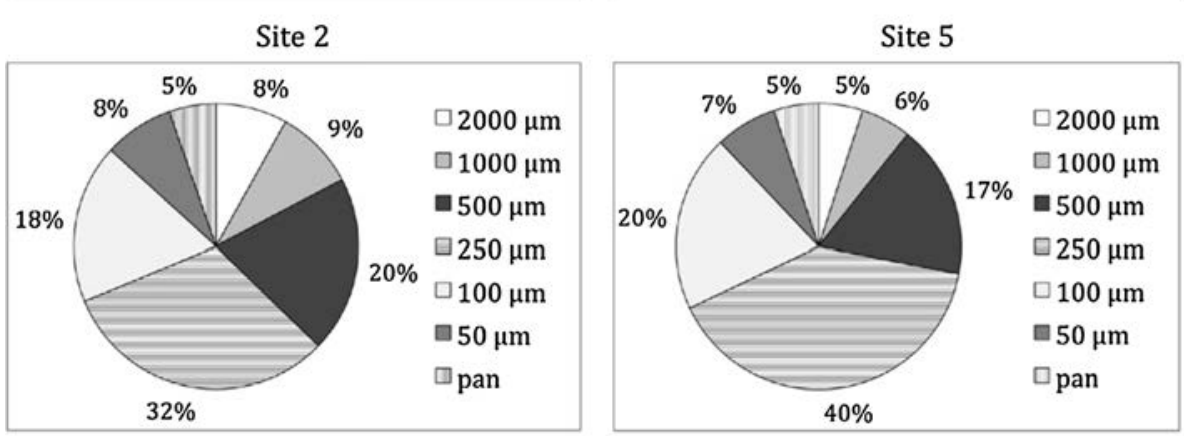

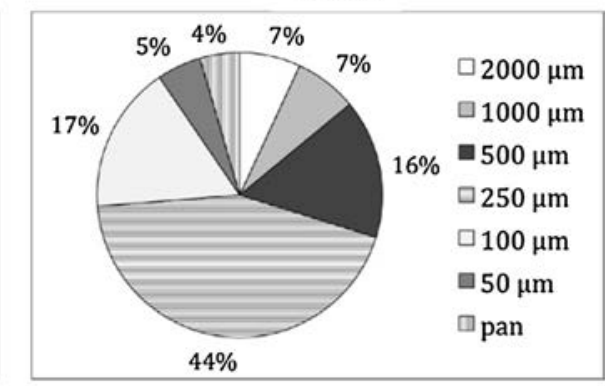

Site 4

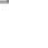

Fig. 6 Particle size distribution at each site

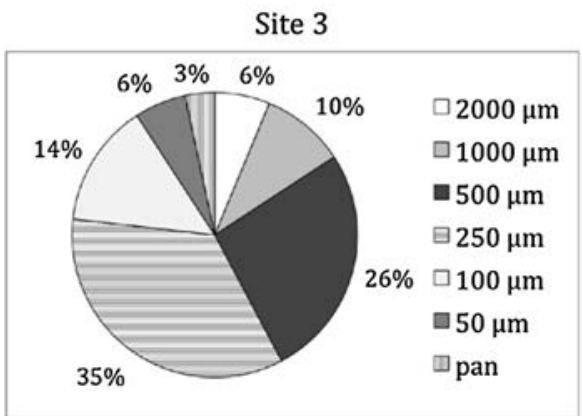



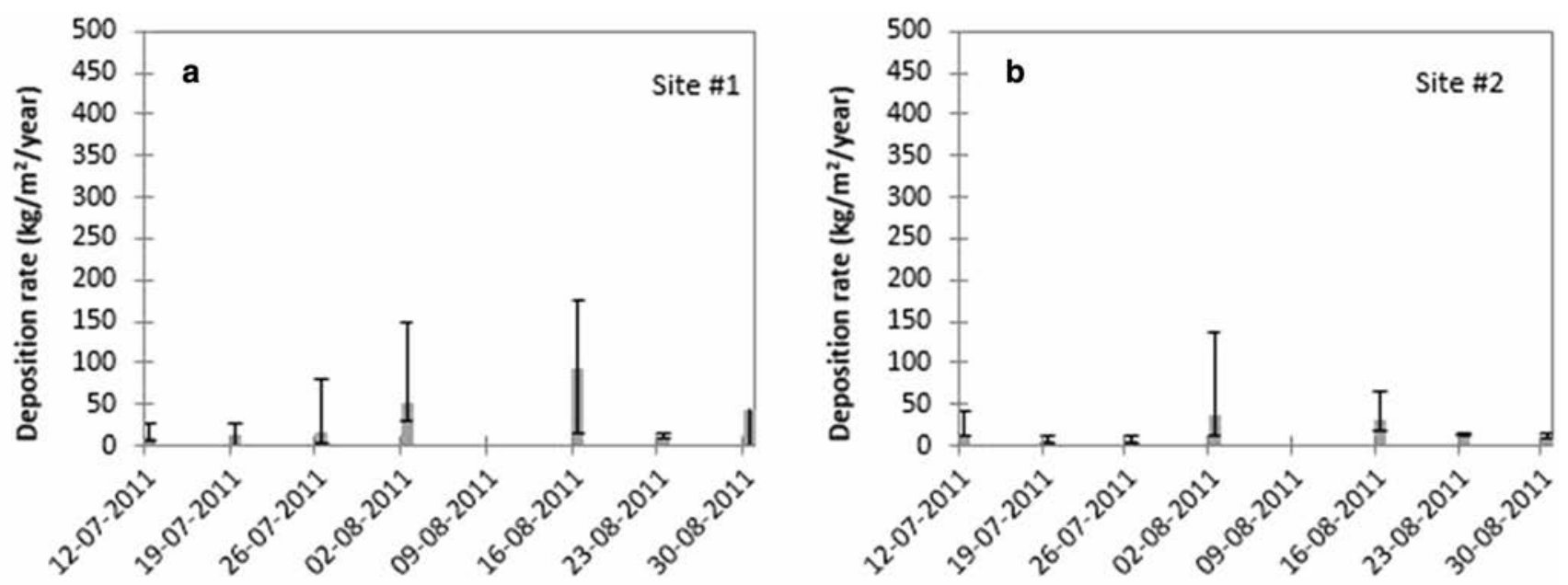

Dates

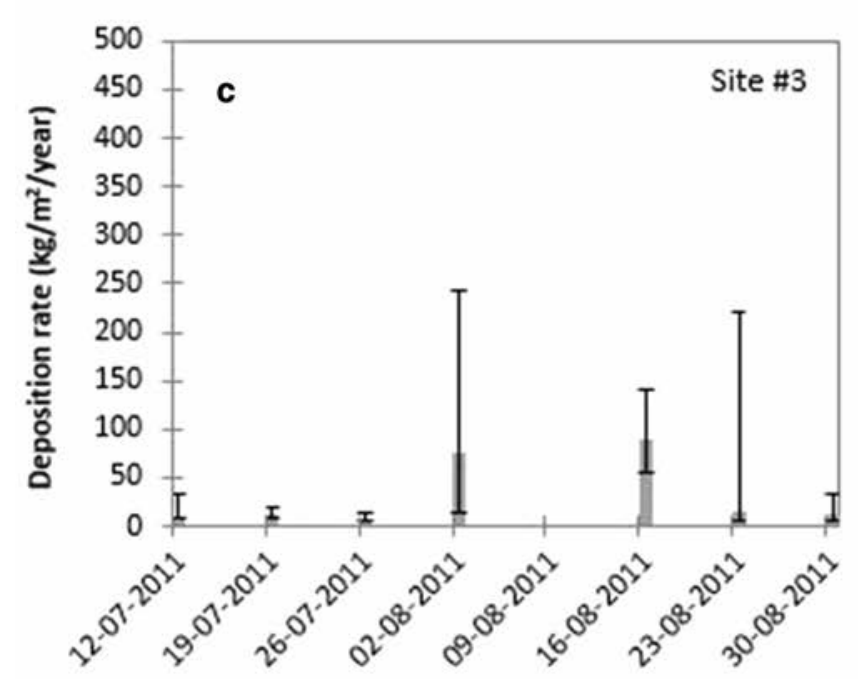

Dates

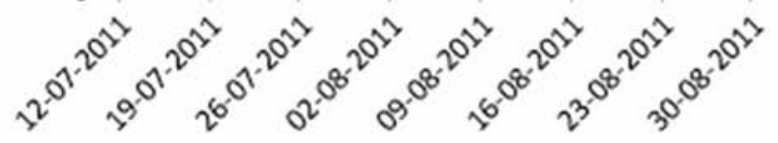

\section{Dates}
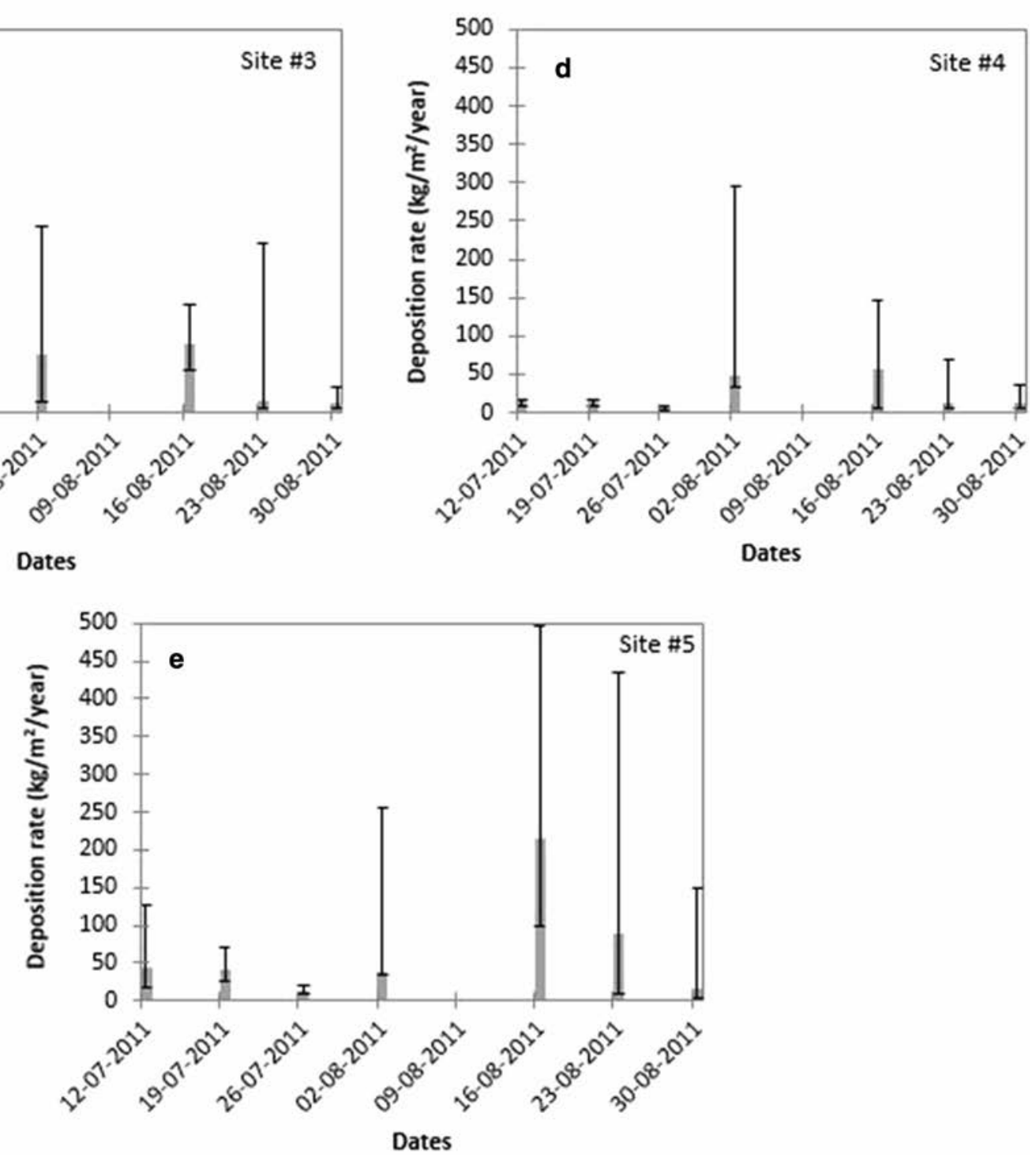

Fig. 7 Deposition rate at site \#1(a), \#2(b), \#3(c), \#4(d), \#5(e) 


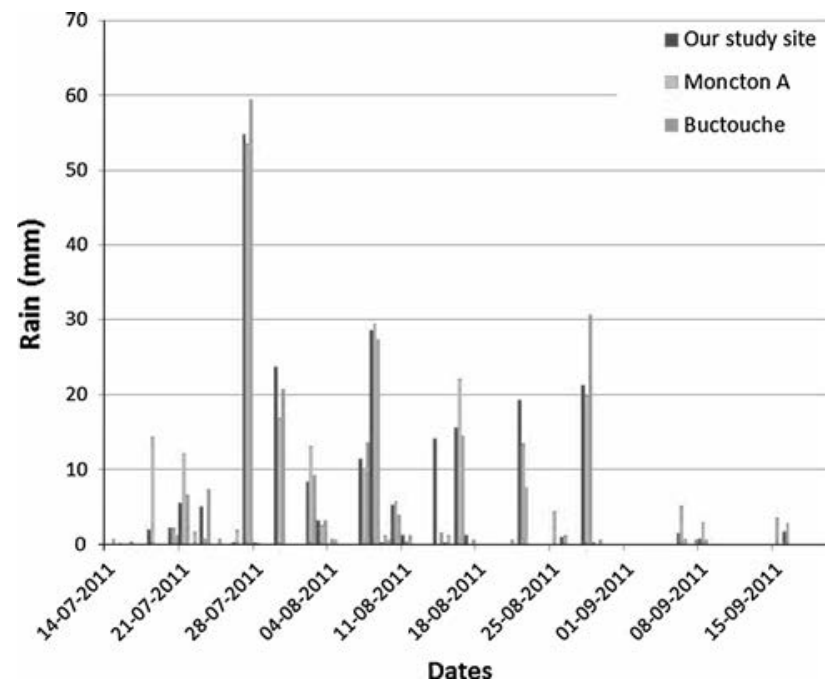

Fig. 8 Quantities of precipitation during summer 2011 at three weather stations

noticeable in the $250 \mu \mathrm{m}$ class, with a decrease of $13 \%$ from site 1 to site 5 . The grain size is particularly important for the early stages of fish development. For example, Peterson and Metcalfe (1981) have shown that finer sand (size under $220 \mu \mathrm{m}$ ) can affect the emergence rate of salmon. The increase in the proportion of coarse sand may be associated with anthropogenic activities and may thus be more closely related to point sources of erosion, mainly dirt roads and the passage of ATVs in the river. This is consistent with what was reported by participants during the interviews. On the other hand, some interviewees reported having noticed a siltation. This could be the case for the lower section of the river (sites 4 and 5) where finer sediment $(\leq 250 \mu \mathrm{m})$ is more common than coarse sediment $(>250 \mu \mathrm{m})$. For example, at site 1 fine sediment $(\leq 250 \mu \mathrm{m})$ counted for $54 \%$ of the total sediment retained by the sediment traps while the proportion reached $67 \%$ at site 5 (see Fig. 6). For coarse sediment the opposite situation was observed. This observation is in agreement with Fox (2011) who found that coarse sediments are most common upstream while fine particles move downstream since both erosion and deposition are particle size selective. Moreover, Young (1980) observed that particles between 20 and $200 \mu \mathrm{m}$ are more erodible, which also corroborated our result. However, during grain size measurement a small amount of the sediments remained in the pan (between 3 and $6 \%$ of the total amount) and was not included in the grain size class shown in Fig. 6.

\section{Deposition Rate of Sediments}

The Canadian Water Quality Guidelines for the Protection of Aquatic Life (Canadian Council of Ministers of the
Environment 2002) does not have a threshold for deposited sediments because there is insufficient information available to establish one. Pavey (2006) measured median deposition rates ranging from 1.3 to $67 \mathrm{~kg} / \mathrm{m}^{2} /$ year for disturbed waterways located downstream of an exploited peat area in New Brunswick. Owens and Walling (2002) obtained values between 0.2 and $2.2 \mathrm{~kg} / \mathrm{m}^{2} /$ year for the period from 1963 to mid-1990 and between 0.6 and $5.9 \mathrm{~kg} /$ $\mathrm{m}^{2} /$ year for the period from $1894 / 1895$ to 1963 with the highest values corresponding to a period of intense human activity in the study area. Our median values vary from 0.9 to $496.3 \mathrm{~kg} / \mathrm{m}^{2} /$ year (the highest value was recorded at site 5, August 16, 2011) depending on location and time (Fig. 7). The lower values are in agreement with the observations made by Pavey (2006); Owens and Walling (2002) but our high values are well above her results.

Suspended load can have a significant effect on fish population. While grain size is important, the concentration of sediment and the duration of sediment exposure must also be taken into account to determine sublethal and lethal effects (Robertson et al. 2006).

\section{Meteorological Conditions}

As mentioned above, the total amount of water and the intensity of rainfall events are critical factors for water erosion and transportation. Soil properties are also important for soil erodibility, as in the case of fine sediment transported into the river after a heavy rain. Two photos taken on July 21, 2011 clearly show this. A first photo was taken at 5:46 PM and a second an hour and a half hour later at 7:16 PM (using a time lapse camera). During the period from 5:30 to 7:30, $5.1 \mathrm{~mm}$ of rain fell (Fig. 8), for a total amount of $0.8 \mathrm{~mm}$ of rain in the first hour (5:30-6:30) and $4.3 \mathrm{~mm}$ in the second hour $(6: 30-7: 30)$ based on data recorded by our rain gage. Moreover, previous results helped us establish a threshold of $20 \mathrm{~mm}$ of rain per day as corresponding to the average amount of rain necessary for a significant contribution of sediments to be observed in the watercourse as measured by our sediments traps. This threshold was exceeded four times during our study period (54.9 mm on 27th July; $23.8 \mathrm{~mm}$ on 30th July; 29.4 on 8th August; $21.3 \mathrm{~mm}$ on 28th of August). For these four rain events the maximum values for the deposition rate were all measured at site \#5 and varied from 148.4 to $496.3 \mathrm{~kg} / \mathrm{m}^{2} /$ year as shown in Fig. 7. This amount of sediment is closely linked to precipitation, turbidity, and grain size data. For a disturbed area Barton (1977) has also recorded maximum suspended solids levels during a sudden rainstorm, but the amount of precipitation brought during this event is not available.

Although the influence of rain on erosion was rarely mentioned during the interviews, it exerts a significant influence on the sediment dynamic in a watershed. Some 
participants mentioned that they noticed an increase in erosion and sediment in the river after heavy rains or a thaw. This is significant since a good way to reduce the amount of sediment in the water is to reduce activities that promote erosion due to heavy rains and thaw. With measurements of deposition rate and rainfall recorded, we were able to determine the critical threshold of heavy rain (20 $\mathrm{mm})$, beyond which a large amount of sediment goes into the river. This threshold applied to the river in our study could be used to restrict activities having adverse effects on erosion and sedimentation such as using dirt roads or ATV trails after heavy rains or during the spring thaw.

\section{Conclusions}

The use of different data sources to document erosion and sedimentation in a watershed can improve and diversify the quantity and quality of information. Interviews are useful to better understand the current and past state of the river and its watershed. Multiple data sources can also help identify the main sources of potential water erosion and locate the most sensitive erosion areas. In addition, the RUSLEFAC, based on several factors from various data sources, was useful to classify potential losses of soil and prepare a simplified map with these data. The area most susceptible to water erosion can be located and linked to the information from the interviews in order to provide a more thorough study of the watershed. We were able to identify and locate erosion-sedimentation problems from the information collected during the interviews. However, we also found that this information is not always consistent with the results from other methods. For example, the map produced from RUSLEFAC showed some erosion prone areas. These areas at increased risk of erosion were especially steep sites located near the river on bare soil or nonforest land. However, the interviewees' concerns for the erosion problems were rather limited to very specific sites and mainly linked to malpractice or negligence by land users (e.g., VTT). Moreover, collecting in situ data (turbidity, grain size, and deposition rate) combined with the acquisition of meteorological data is a useful way to provide a state of the river on a quantitative basis. This is helpful to better understand how the river reacts to rainfall and to determine the background values for turbidity and deposition rate for example. This in situ information can also be used to establish some thresholds at which the sediments are more prone to be transported and deposited either in the watershed or in the river. In situ data can be used to verify and validate some observations that are related to the perception of participants by quantifying certain variables (increased sedimentation, reduced water turbidity). However, since our study was conducted over 1 year it is not possible to generalize.

In conclusion, this pilot study combines various methods based on various data sources from both the social sciences (interviews) and natural sciences (RUSLEFAC and in situ measurements). One challenge for stream studies is not only to better understand both watersheds and stream processes but also to match this information with the social, economic, and politic drivers of the urban (Walsh et al. 2005) and rural environments. We have thus been able to establish thresholds for deposition rates. These thresholds could either be used for rivers with similar characteristics in the same area or serve as a comparison in future studies at larger scales.

Some limitations exist in this study. The information gathered in the interviews is more representative of the recent period (week or last month) than recent years or even decades. The location of interviewee's house/activities along the river probably affects their perception of the river in general. In future work, more information about interviewees could be gathered in order to analyze their responses based on their profiles and geographical position. Future investigations of the local population's perception associated with an approach that allows describing the variation in time should be conducted for a better understanding of spatiotemporal change in the area over the last years or decades.

Acknowledgments The authors would like to thank Julie Mallet and Janelle McLaughlin for carrying out part of the field measurements, data analysis, and laboratory work. Alida Thiombiano, Julie Mallet, Nicolas Bastien, and Jacinthe Roberge for conducting interviews and/or their analysis. Jeremy Hayhoe for his proof-reading assistance. Yves Blanchard for the RUSLEFAC mapping. We also want to acknowledge our partners Jocelyne Gauvin, Rémi Donelle, and Nathalie LeBlanc for their help and comments during and throughout the duration of the project. Finally, a special thanks to all the participants who helped us during the interviews. This project has been financially supported by Environmental Trust Fund of New Brunswick and New Brunswick Wildlife Trust Fund.

\section{References}

Allmendinger NE, Pizzuto JE, Moglen GE, Lewicki M (2007) A sediment budget for an urbanizing Watershed, 1951-1996, Montgomery County, Maryland, U.S.A. J Am Water Resour Assoc 43(6):1483-1498. doi:10.1111/j.1752-1688.2007.00122.x

Arndt SKA, Cunjak RA, Benfey (2002) Effect of summer floods and spatial-temporal scale on growth and feeding of juvenile Atlantic salmon in Two New Brunswick streams. Trans Am Fish Soc 131(4):607-622

Barrera-Bassols N, Zinck JA (2003) Ethnopedology: a worldwide view on the soil knowledge of local people. Geoderma 111:171-195 
Barton BA (1977) Short-term effects of highway construction on the limnology of a small stream in southern Ontario. Freshw Biol 7:99-108

Baum F, MacDougall C, Smith D (2006) Participatory action research. J Epidemiol Commun Health 60(10):854-857

Bell S, Morse S, Shah RA (2012) Understanding stakeholder participation in research as part of sustainable development. J Environ Manag 101:13-22

Berkes F (2004) Rethinking community-based conservation. Conserv Biol 18:621-630

Berkes F (2007) Adaptive co-management and complexity: exploring the many faces of co-management. In: Armitage D, Berkes F, Doubleday $\mathrm{N}$ (eds) Adaptive co-management. University of British Columbia Press, Vancouver, pp 19-37

Berkes F (2009) Community conserved areas: policy issues in historic and contemporary context. Conserv Lett 2:19-24

Berkes F, Berkes MK, Fast H (2007) Collaborative integrated management in Canada's north: the role of local and traditional knowledge and community-based monitoring. Coast Manag 35(1):143-162

Bloesch J, Burns NM (1980) A critical review of sedimentation trap technique. Schweiz Z Hydrol 42(1):15-55

Bryan RB (2000) Soil erodibility and processes of water erosion on hillslope. Geomorphology 32:385-415

Canadian Council of Ministers of the Environment (2002) Canadian water quality guidelines for the protection of aquatic life: total particulate matter. In: Canadian environmental quality guidelines, 1999, Canadian Council of Ministers of the Environment, Winnipeg

Caissie C (2006) The impact of fine sediment of the Chockpish, Boutouche, Little Boutouche and Cocagne Rivers. Report for the New Brunswick Environmental Trust Fund, pp 16

Collins AL, Walling DE (2004) Documenting catchment suspended sediment sources: problems, approaches and prospects. Prog Phys Geogr 28(2):159-196

Delisle S, Dubé M (2001) L'impact des ponceaux sur le milieu aquatique forestier: un nouvel outil de mesure. Info Forêt, 69

Department of Environment, Canada (2011). National Climate Data and Information Archive. http://www.climate.weatheroffice.gc. ca/advanceSearch/searchHistoricData_e.html?Prov=NB\&Station ID $=9999 \&$ Year $=2012 \&$ Month=3\&Day=12\&timeframe Accessed 7 Aug 2011

Dubé M, Delisle S, Lachance S, Dostie R (2006) L'impact de ponceaux aménagés en milieu forestier sur l'habitat de l'omble de fontaine, Québec, Gouvernement du Québec, ministère des Ressources naturelles et de la Faune, Direction de l'environnement forestier et Direction de l'aménagement de la faune de la Mauricie et du Centre-du-Québec, pp 62

Dunlap RE, Michelson W (eds) (2002) Handbook of environmental sociology. Greenwood Press, Westport

Fortin M-F (2010) Fondements et étapes du processus de recherche. Méthodes quantitatives et qualitatives. Chenelière education, Montréal

Fox DM (2011) Evaluation of the efficiency of some sediment trapping methods after a Mediterranean forest fire. J Environ Manag 92:258-265

Gao P (2008) Understanding watershed suspended sediment transport. Prog Phys Geogr 32(3):243-263

Gauvin J, Turcotte-Lanteigne A, Ferguson E (2009) Rapport d'ensemble de l'écosystème de la baie de Cocagne au Nouveau-Brunswick. Rapport Manuscrit Sciences Halieutiques 2869

Ice GG (1986) A study of the effectiveness of sediment traps for the collection of sediment from small forest plot studies. Technical Bulletin 483, NCASI
Kindon N (2010) Participation. In: Smith SJ, Pain R, Marston SA, John JP III (eds) The Sage handbook in social geographies. Sage Publications Ltd, London, pp 517-545

Kummu M (2009) Water management in Angkor: human impacts on hydrology and sediment transportation. J Environ Manag 90:1413-1421

Lachance S, Dubé M (2004) A new tool for measuring sediment accumulation with minimal loss of fines. N Am J Fish Manag 24:303-310

Lewis J (1998) Evaluating the impacts of logging activities on erosion and suspended sediment transport in the Caspar creek Watersheds. USDA Forest Service General technical Report. PSWGTR-168-Web

Ligonja PJ, Shrestha RP (2013) Soil erosion assessment in Kondoa eroded area in Tanzania using Universal Soil Loss Equation, Geographic Information Systems and socioeconomic Approach. Land Degrad Dev. doi:10.1002/ldr.2215

Luce CH, Black TA (1999) Sediment production from forest roads in western Oregon. Water Resour Res 35(8):2561-2570

Mamun AA (2010) Understanding the value of local ecological knowledge and practices for habitat conservation in humanaltered floodplain systems: a case from Bangladesh. Environ Manag 45:922-938

Mustelin J, Klein RG, Assaid B, Sitari T, Khamis M, Mzee A, Haki T (2010) Understanding current and future vulnerability in coastal settings: community perceptions and preferences for adaptation in Zanzibar, Tanzania. Popul Environ 31:371-398

Nearing MA, Govers G, Norton LD (1999) Variability in soil erosion data from replicated plots. Soil Sci Soc Am J 63(6):1829-1835

Owens PN, Walling DE (2002) Changes in sediment sources and floodplain deposition rates in the catchment of the river Tweed, Scotland, over the last 100 years: the impacts of climate and land use change. Earth Surf Process Landf 27:403-423

Pandey A, Chowdary VM, Mal BC (2007) Identification of critical erosion prone areas in the small agricultural watershed using USLE, GIS and remote sensing. Water Resour Manag 21:729-746

Parlee B, Berkes F, Teetl'it Gwich'in Renewable Resources Council (2006) Indigenous knowledge of ecological variability and commons management: a case study on berry harvesting from northern Canada. Hum Ecol 34:515-528. [Online accessed 4 May 2013]

Paul MJ, Meyer JL (2001) Streams in the urban landscape. Annu Rev Ecol Evol Syst 32:333-365

Pavey B (2006) Analyse comparative des concentrations de solides en suspension et de la sédimentation en aval de tourbières exploitées. Master Degree Thesis, Université du Québec, INRS-Eau, Terre et Environnement

Peterson RH, Metcalfe JL (1981) Emergence of Atlantic salmon fry from gravels of varying compositions: a laboratory study. Canadian technical report of fisheries and aquatic science No. 1020

Pimentel D, Harvey C, Resosudarmo P, Sinclair K, Kurz D, McNair M, Crist S, Shpritz L, Fitton L, Saffouri R, Blair R (1995) Environmental and economic costs of soil erosion and conservation benefits. Science 267(5201):1117-1123

Renard KG, Foster GR, Weesies GA, McColl DK, Yoder DC (1997) Predicting soil erosion by water: a guide to conservation planning with the Revised Universal Soil Equation (RUSLE). Agriculture Handbook, No.703

Robertson MJ, Scruton DA, Gregory RS, Clarke KD (2006) Effect of suspended sediment on freshwater fish and fish habitat. Canadian Technical Report of Fisheries and Aquatic Sciences, No. 2644

Slaymaker O (2003) The sediment budget as conceptual framework and management tool. Hydrobiologia 494:71-82 
Smith SJ, Pain R, Marston SA, Jones JP III (2010) Introduction: situating social geographies. In: Smith SJ, Pain R, Marston SA, John JP III (eds) The Sage handbook in social geographies. Sage Publications Ltd, London, pp 1-39

Trahan N (2002) Modeling Sediment and Contaminant Pathways to the Cedar River. http://proceedings.esri.com/library/userconf/ proc02/pap0785/p0785.htm

Wall GJ, Coote DR, Pringle EA, Shelton IJ (eds) (2002) RUSLEFAC-Revised Universal Soil Loss Equation for Application in Canada: A handbook for estimating soil loss from water erosion in Canada. Research Branch, Agriculture and Agri-Food Canada, Ottawa. Contribution No. AAFC/AAC2244E
Walsh CJ, Roy AH, Feminella JW, Cottingham PD, Groffman PM, Morgan RP II (2005) The urban stream syndrome: current knowledge and the search for a cure. J N Am Benthol Soc 24(3):706-723

Wischmeier WH, Smith DD (1978) Predicting rainfall erosion losses - a guide to conservation planning. U.S. Department of Agriculture, Agriculture Handbook No. 537

Young RA (1980) Characteristics of eroded sediment. Trans ASAE 23(1139-1142):1146 